\title{
Psychological Aspects of Official Activities of Police Officers of Cargo and Mobile Objects Security Orders
}

\author{
Volodymyr Ostapovich [0000-0003-4962-0975], Vadym Barko *[0000-0002-3836-2627], \\ Liubov Protsyk [0000-0002-5440-5826] \\ State Research Institute of the Ministry of Internal Affairs of Ukraine, Kyiv, Ukraine \\ *barkoua@ukr.net
}

\begin{abstract}
The article is devoted to the generalization of psychological aspects of the service activities of police officers of cargo and mobile objects of the security police as one of the components of the National Police of Ukraine. On the basis of a large-scale experimental study with the participation of 280 police officers, psychological and some sociolegal aspects of police activities, individual characteristics of specialists in this field were identified. The article proves that the profession of police officer of cargo and mobile objects security orders makes high demands on the psychophysiological and individual psychological qualities of employees; he needs to have advanced cognitive processes. The profession makes certain demands on the individual psychological characteristics of police officers (level of intellectual abilities, degree of creativity and formation of thinking operations, in particular, induction and deduction, comparison, generalization, separation of the main. A police officer must be able to influence the opponent, be a good communicator, be responsible for their actions and accurately evaluate the actions of others, if necessary to convince citizens of their rightness, to be proactive, active, but legible in contacts. Important for the successful performance of official functions of the security police officer are also managerial, organizational and special abilities. The article also presents a list of individual characteristics that do not contribute to the success of official activities in the position of police officer of cargo and mobile objects security orders, the main of which are: insufficient strength and lability of nervous processes, low level of cognitive development processes (perception, attention, memory, thinking, insufficient level of intelligence; accentuation of character and temperament; negative character traits; low level of communication skills, etc.
\end{abstract}

Keywords: policeman, police officer of cargo and mobile objects security, professionally important qualities, abilities, motivation, characterological features, psychogram.

\section{INTRODUCTION}

The security police is an important component of the National Police of Ukraine (NPU), which is tasked with providing services for the protection of property and citizens. According to the Law of Ukraine "On the National Police", it is the only security structure in Ukraine, whose employees have the rights and powers defined by law for armed protection and the use of official functions against offenders [1]. With the further development of the rule of law and democracy in Ukraine, the importance of the problem of reliable protection of the rights and legitimate interests of citizens is growing, which includes the introduction of effective mechanisms for security police [2-6]. As part of the security police - to ensure the protection of cargo and mobile objects - appropriate units from police officers of cargo and mobile objects security are formed [3].

The official activity of police units of cargo and mobile objects security (PUCMO) is accompanied by a number of professional law enforcement functions and requires the police to have certain personal qualities, as well as legal knowledge, special skills, basic and general professional competencies.Therefore, the study of psychological aspects of the work of employees of this specialty, the development of criteria for their professional selection when appointing to positions is an urgent task.

\section{LITERATURE REREVIEW}

Domestic scientists have devoted a lot of scientific work to the study of psychological features of 
policing (O. Alexandrov, V. Androsyuk, O. Bandurka, V. Barko, I. Dubova, V. Kryvolapchuk, O. Kudermina, Y. Irkhin, L. Kazmirenko, T. Nescheret, V. Medvedev, V. Ostapovich, O. Shapovalov and others). The scientific developments of these researchers consider the psychological structure of law enforcement officers, provide socio-psychological and information models of the most important specialties of the Ministry of Internal Affairs of Ukraine, offer forms and methods of psychological selection and training of employees [7-8].

Among foreign scholars on this issue should be noted such researchers as C. Bouchard, W. Borman, R. Cochraine, M. Dunnett, R. Miguel, J. Hurd, S. Lueke, J. Tan, R. Tett, L. Vandecreek and others. [9-11]. In the scientific works of the authors, attention is paid to topical issues of police psychology (G. Barrett, R. Cochraine) [12-14]. However, the psychological aspects of the activities of security police officers are insufficiently studied.

The purpose of the article is to establish and summarize the most important psychological features of the service activities of police officer of cargo and mobile objects security. To implement it, the following tasks must be performed: a) to analyze the regulations governing the activities of police units of cargo and mobile objects security; b) determine the psychological characteristics of official activity of the police officers of cargo and mobile objects security; c) to develop a psychogram of the activities of the police officer of cargo and mobile objects security.

The survey was conducted during 2020 and covered 280 police officers (all men) aged 22 to 40 , special ranks - from sergeant to lieutenant colonel. The number of respondents meets the requirements for representativeness, based on the general population of police officers (about eight thousand people with a confidence level of probability of 0.95 with a theoretical statistical error of 0.05).

The object of research is the psychological features of the service activities of police officers of cargo and mobile objects security, and the subject - professionally important personal characteristics of police officers.

The scientific novelty of the study is that for the first time on the basis of extensive and empirical research and analysis of literature sources the authors have established the psychological characteristics of police officers of cargo and mobile objects security, as well as professionally important qualities of specialists in this field of professional activity.

\section{METHODOLOGY}

Analysis and systematization of scientific sources on research, observation, questionnaires, objective and subjective methods of psychological diagnosis, statistical processing of results [15-17].
To achieve the goal of the research we used a number of psychodiagnostic techniques:

1. To diagnose the features of self-actualization used the Jones-Crandall scale, developed in 1986 by A. Jones and R. Crandall [18].

2. The Individual-Typological Inventory (ITI) (L. Sobchyk) was used to identify the actual personality tendencies). This Inventory allows you to determine the typological features of the police officer on the basis of a model built in an orthogonal coordinate system. Typological features are polar (extroversion introversion; aggression - neuroticism, etc.) [19].

3. In order to establish the degree of accentuation of characterological and temperamental traits, the Leonhard-Shmishek Inventory was used (K. Leongard), which allows the diagnosis of ten accentuations of a police officer's personality [20].

4. To study the creative potential of the individual we used a method developed by V. Mede and K. Piorkovsky, which involves assessing the intellectual abilities of the person (the ability to combine; the amount of vocabulary; the ability to make logical judgments, etc.) [21].

5. To study the features of intellectual development we used the test of R. Amthauer (subtests 2; 3 ) - to establish the level of verbal intelligence, as well as subtests 6 - allows to determine the level of nonverbal (practical) intelligence [20].

6. To study the properties of the nervous system of the individual we used tapping test (modified by E. Ilyin), which makes it possible to establish indexes of strength and mobility of nervous processes [21].

7. To study the communicative capabilities of police officers we used an inventory for the diagnosis of interpersonal interaction - DII (T. Leary), which allows to establish the main features of interpersonal communication of the individual [22].

8. The Richie-Martin test was used to study the peculiarities of police motivation (S. Richie, P. Martin), which allows to determine what needs a person seeks to realize in the process of official activity [23].

9. To determine the general structure of the personality using five factors (extraversion, consciousness, agreeableness, neuroticism, openness to experience) - used the Big Five Inventory (BFI), developed in 2008 O. John, L. Naumann and S. Soto [24].

\section{RESULTS}

In the course of the research it was established that the profession of police officer of cargo and mobile objects security puts forward certain requirements to the sensory-perceptual sphere of personality. The police officer must have a sufficient level of functional activity 
of the brain, high sensitivity of visual (good vision and eye), auditory (good hearing and the ability to localize sounds in space), tactile and olfactory analyzers; developed vestibular apparatus, well oriented. According to the regulations for police officers of cargo and mobile objects sequrity, the omega potential of the police officer should be in the range from 20 to $40 \mathrm{mV}$, which reflects the optimal level of brain function, indicates the ability to withstand prolonged mental and physical stress while maintaining high efficiency, optimal mobility of nervous processes, easy attention, good RAM and long-term memory. The critical frequency of light flickers (LFS) for the right eye should be not less than $35 \mathrm{~Hz}$ and asymmetry not more than 2.6 $\mathrm{Hz}$, which indicates sufficient state of all systems.

The official activity of the police officer of cargo and mobile objects security requires from the policeman a rather high level of development of psychomotor features. It needs to have a sufficiently high speed of simple visual-motor reaction (SVMR) and reaction to a moving object (RMO); high accuracy and coordination of movements. The maximum allowable value of SVMR is up to $230 \mathrm{~ms}$, the average value of the deviation of the RMO does not exceed $50 \mathrm{~ms}$ (according to the table of requirements for individual psychophysiological characteristics).

Also, the police officer of cargo and mobile objects security needs to have well-developed cognitive processes. He needs to be attentive, and attention must be stable, with a large volume and distribution, concentrated and stable. The Grunbaum test time should not exceed 20 $\mathrm{s}$, and the number of errors should not exceed 2 .

The police officer must have a good working and long-term memory; high indicators of visual, auditory, motor verbal-logical and figurative memory; the ability to clearly reproduce information at the right time; ability to easily memorize verbal and logical material; the appropriate level of memory for a person's appearance, as well as the color, shape, size, movement and location of objects.

The thinking of a police officer should be characterized by such features as speed and flexibility. A police officer must have well-developed speech functions, namely, be able to speak accurately, pronounce words clearly and express opinions, give commands and instructions.

The profession of police officer of cargo and mobile objects security makes certain demands on the abilities of employees. A study of the average indicators of the level of development of intellectual abilities using the R. Amthauer test showed that police officers have an intermediate level of verbal (average values range from 10.8-11.5 raw points or 102-105 IQ) and higher than the average level of nonverbal ( practical) intelligence (13.8 $\begin{array}{llll}\text { raw points or } 112 & \text { IQ). A study }\end{array}$ of police creativity showed that they also have an average level of speed of divergent thinking (the average is 4.48 points), as well as originality (7.85).

Special abilities are related to the ability of a police officer to apply police coercive measures and firearms.

The official activity of police officers of cargo and mobile objects security also requires certain communication skills. The survey using the Leary test (DII) showed that police officers have tendencies in communication (which are reflected in the numbers of the following octants): 1 (dominance) - 7.9 points; 7 (sociability, propensity to compromise) - 7.6 points; 8 (responsibility) - 6.6 points; 2 (independence, independence) - 6.2 points. Low scores were recorded for octants 4 (rigidity, suspicion) and 5 (obedience) - 3.15 and 4.15 points, respectively.

This shows that the police officer has leadership qualities, is a good communicator, able to influence people and persuade them, set an example and lead, well control their own emotions. At the same time, he is attentive to the needs and interests of citizens, able to help people and understand them correctly.

Individual psychological features of police officer of cargo and mobile objects security is characterized by a significant strength of nervous processes, able to withstand significant stress.

A study using a Tapping test showed that police officers have several types of profiles. The majority of respondents $(50.0 \%)$ show a medium-strong type of nervous system, a quarter of respondents $(25.0 \%)$ have a medium-weak type, the same proportion of employees $(25.0 \%)$ show a profile characteristic of a strong nervous system. Persons with a weak nervous system were not detected. Most police officers have high (68\%) and medium $(27.0 \%)$ rates of lability of nervous processes, $5 \%$ - low.

The study of the peculiarities of the motivation of the police officers of cargo and mobile objects security showed that the police officer have inherent aspirations (in descending order): 1) high wages and material rewards; 2) clear structuring of work; 3) interesting and socially useful work; 4) gaining recognition so that others appreciate their merits, achievements and successes; 5) independence, autonomy and self-improvement; 6) good working conditions and comfortable environment; 7) set bold goals for yourself and achieve them, be selfmotivated;

The study found that police officers have a fairly high level of self-actualization. According to the JonesCrandall questionnaire, the average value of the level of self-actualization is 45.28 points out of 60 possible, which is a high figure.

Features of character. The study of typological features of the personality of the police officers of cargo 
and mobile objects security on the basis of the use of ITI allows to characterize employees as people with a sthenic type of response, active, independent, man with bright, but controlled emotions.

Analysis of the individual profile allows us to conclude that it is linear, located in the "corridor" from 3 to 6.7 points. There are rises on scales 1 - extraversion (6.77 points); 8 - lability (5.35) and 2 - spontaneity (5.68), 4 - rigidity (5.57) (meaning stenic type response). The profile of the policeman also has in its configuration an increase on a scale of 4 - rigidity (5.57), which indicates some stubbornness, suspicion, punctuality, attention to detail, pedantry, good selfcontrol, stress resistance and steadfastness of the policeman.

The results of the study using the individualtypological inventory (ITI) allow us to conclude that the following variations of profile types are typical for police officers of cargo and mobile objects security : a) increase on scales 1 and 2 - police officers are optimistic, somewhat aggressive, prone to risk , but they are characterized by somewhat reduced selfcontrol; b) scales 1 and 8 are recorded as leading - such persons are active, persistent, consistent and purposeful, but may show some emotional instability, mood swings, demonstrativeness, selfishness, tendency to dramatize events; c) personal profile with leading scales 2 and 4 - a combination of such tendencies leads to the fact that police officers are characterized by a balance of stenic and egocentric traits; such persons are characterized by a high degree of harassment, motivation to achieve, sociability, persistence and diligence, practicality.

Using the Big Five Inventory, it was found that police officers of cargo and mobile objects security have such traits as high consciousness in their work (average value - 36.17 points, significant openness of experience (33.11 points), moderate extroversion $(29.80$ points) and agreeableness (33.9 points), low levels of neuroticism (14.33 points).

The results obtained on the basis of the LeonhardShmishek Inventory allow us to conclude that there are no people with characteristic or temperamental accentuations among the police.

The profile of the police officer contains insignificant increases on scales: 5 (hyperthymic) - average indicator 14,6 points; $1 \quad$ (demonstrativeness) - 12.7; 2 (meticulousness) - 10.7; 3 (stuck) - 10.7; 10 (exaltation) - 10.6; 8 (cyclothymic) - 9.2. Accentuations of such traits as anxiety, excitability, dysthymia, emotionality in police officers were not detected; the indicators are in the range of 5-7 points.

Based on the data obtained, it is possible to conclude that the police officer of cargo and mobile objects security has emotional and volitional qualities, such as optimism, zest for life, energy; sociability; ability to easily establish contacts and be a leader; initiative; ability to overcome difficulties; the ability to self-regulate and the ability to objectively assess their strengths and capabilities, to take responsibility; ability to restrain oneself in conflict and stressful situations, to act decisively. In addition, the police are characterized by high efficiency, endurance; balance, emotional stability, heightened moral sense, sensitivity, willingness to help.

The generalized psychogram of the police officer of cargo and mobile objects security presented in Table 1.

\section{DISCUSSION}

The analysis of the results of research of foreign and domestic scientists in general confirms the indicators obtained by us, which characterize the psychological aspects of police service. Thus, in particular, many researchers (Barrett, Miguel, Hurd, Lueke, Tan, Barko, Irkhin, \& Neshcheret) [2526] emphasize that policing requires many individual qualities and personal characteristics from employees. Thus, it is noted that the appointment of a police officer requires careful multi-day professional selection procedures, which include social, medical, physiological, psychological and physical components. Mistakes in the professional selection of candidates for police work can cost society dearly (not only financially but also socially).

Psychological selection of employees for the police is also given considerable attention by scientists. Thus, in order to study the personal characteristics of police officers use the questionnaires used in our study Big Five Inventory (BFI), Leary's Interpersonal Behavior Circle (LIBC), MMPI-2, as well as Rorshah test, California Psychological Inventory (CPI), Eysenck Personal Questionnaire (EPQ) etc.

Also note the prognostic indicators of successful work of the police, for example, characterological features - stress resistance, emotional stability, honesty, openness, sociability, extroversion (based on the results of the Big Five Inventory] and the California Personal Inventory $[\mathrm{CPI}])$. Studies by various authors also confirm the presence of positive correlations of these personal qualities of police officers with indicators of success of their professional activities, although the correlation coefficients are low (0.30-0.37) (Barrett, Miguel, Hurd, Lueke, \& Tan; Gough).

Foreign researchers emphasize that police officers must have professionally important individual psychological qualities, in particular, their official activities make quite high demands on the level of intellectual abilities of a person. 
Table 1. Generalized psychogram of police officer

\begin{tabular}{|c|c|c|c|c|}
\hline № & $\begin{array}{c}\text { Individual } \\
\text { psychological } \\
\text { characteristics }\end{array}$ & Measured parameters & $\begin{array}{l}\text { Psychodiagnostic } \\
\text { techniques }\end{array}$ & $\begin{array}{l}\text { Indicators of professional } \\
\text { suitability }\end{array}$ \\
\hline 1 & Brain activity & $\begin{array}{l}\text { The level of functional } \\
\text { activity of the brain }\end{array}$ & $\begin{array}{l}\text { Methods for determining the } \\
\text { omega potential of the brain }\end{array}$ & $\begin{array}{l}\text { The value of the omega potential is } \\
\text { in the range of } 20-40 \mathrm{mV} \text {. }\end{array}$ \\
\hline \multirow[t]{2}{*}{2} & \multirow[t]{2}{*}{$\begin{array}{l}\text { Psychomotor } \\
\text { processes }\end{array}$} & $\begin{array}{l}\text { The speed of a simple } \\
\text { visual-motor reaction }\end{array}$ & $\begin{array}{l}\text { Method for determining the } \\
\text { speed of SVMR }\end{array}$ & Speed no more than $230 \mathrm{~ms}$. \\
\hline & & $\begin{array}{l}\text { Response rate to a } \\
\text { moving object }\end{array}$ & $\begin{array}{l}\text { Methods for determining the } \\
\text { speed of RMO }\end{array}$ & $\begin{array}{l}\text { The average value of the deviation } \\
\text { does not exceed } 50 \mathrm{~ms} \text {. }\end{array}$ \\
\hline 3 & $\begin{array}{l}\text { Properties of the } \\
\text { nervous system }\end{array}$ & $\begin{array}{l}\text { Strength and lability of } \\
\text { nervous processes }\end{array}$ & Taping test & $\begin{array}{l}\text { High or medium lability of nervous } \\
\text { processes (number of touches } \\
\text { in } 30 \mathrm{~s} \text { - more than 160). }\end{array}$ \\
\hline \multirow[t]{2}{*}{4} & \multirow[t]{2}{*}{$\begin{array}{l}\text { Attentional } \\
\text { processes }\end{array}$} & $\begin{array}{l}\text { Features of distribution } \\
\text { and switching of } \\
\text { attention }\end{array}$ & Grunbaum test & $\begin{array}{l}\text { The test execution time does not } \\
\text { exceed } 20 \mathrm{~s} \text {, the number of errors is } \\
\text { not more than } 2 \text {. }\end{array}$ \\
\hline & & Features of memory & $\begin{array}{l}\text { Test "Memorizing } 10 \\
\text { words" }\end{array}$ & $\begin{array}{l}\text { Ascending type of memory curve, } \\
\text { the number of recorded words in the } \\
\text { first attempt - not less than } 6 \text {, at the } \\
\text { end - not less than } 8 \text {. }\end{array}$ \\
\hline 5 & General abilities & $\begin{array}{l}\text { Level of verbal and } \\
\text { nonverbal intelligence }\end{array}$ & Amthauer test & $\begin{array}{l}\text { Average or above average level } \\
\text { of verbal intelligence (not less than } \\
94 \text { IQ); average and higher level of } \\
\text { nonverbal intelligence (at least } 96 \\
\text { IQ). }\end{array}$ \\
\hline 6 & $\begin{array}{l}\text { Communication } \\
\text { skills }\end{array}$ & $\begin{array}{l}\text { Type of interpersonal } \\
\text { interaction, leadership } \\
\text { potential }\end{array}$ & Leary's test (DII) & $\begin{array}{l}\text { Indicators do not exceed } 8 \text { points. } \\
\text { Predominance in the octant profile is } \\
\text { desirable: } 1 \text { (leadership), } 7 \\
\text { (cooperation), } 8 \text { (responsibility). }\end{array}$ \\
\hline \multirow[t]{3}{*}{7} & \multirow[t]{3}{*}{$\begin{array}{l}\text { Characterological } \\
\text { Features }\end{array}$} & Leading trends & $\begin{array}{l}\text { Individual-typological } \\
\text { Inventory (ITO) }\end{array}$ & $\begin{array}{l}\text { Stenic type of response. Indicators of } \\
\text { scales } 1-4-\text { not less than } 4 \text { points, } \\
\text { and scales } 5-8-\text { not more than } 7 \\
\text { points. }\end{array}$ \\
\hline & & $\begin{array}{l}\text { Scales of the Big Five } \\
\text { (extraversion, } \\
\text { neuroticism, } \\
\text { consciousness, } \\
\text { agreeableness, } \\
\text { openness) }\end{array}$ & Big Five Inventory (BFI) & $\begin{array}{l}\text { Neuroticism index not higher than } 20 \\
\text { points; agreeableness - not more than } \\
40 ; \text { consciousness - not less than } 35 \text {, } \\
\text { openness - not less than } 35 \text {. }\end{array}$ \\
\hline & & Accentuations & $\begin{array}{l}\text { Leonhard-Shmishek } \\
\text { Inventory }\end{array}$ & $\begin{array}{l}\text { No signs of accentuation. Indicators } \\
\text { of scales №№ } 1 ; 5 \text { do not exceed } 17 \\
\text { points; №№ } 2 ; 3 ; 6 ; 8 ; 9 ; 10 \text { do not } \\
\text { exceed } 13 \text { points; №4; } 7 \text { do not } \\
\text { exceed } 10 \text { points. }\end{array}$ \\
\hline 8 & $\begin{array}{l}\text { Personality } \\
\text { orientation }\end{array}$ & Features of motivation & Richie-Martin test & $\begin{array}{l}\text { Along with the importance of wages, } \\
\text { the presence in the first positions of } \\
\text { the motives for structuring work, the } \\
\text { presence of feedback; interesting and } \\
\text { socially useful work; recognition by } \\
\text { others; independence, autonomy and } \\
\text { self-improvement; setting bold goals. }\end{array}$ \\
\hline
\end{tabular}


It is proved that a police officer must also have the appropriate psychophysiological and psychomotor qualities - the strength of the nervous system and speed of reaction; he needs the formed cognitive processes perception on the basis of all analyzers; stable and concentrated attention, developed operative and longterm memory; speed of thinking, ability to perform various intellectual operations (Cochraine, Tett, \& Vandecreek; Bouchard, Blair, \& Haskell; Hays, Regoli, \& Hewitt; Kazmirenko, \& Moiseyev; Ostapovych, Dubova, \& Barko).

Also relevant for police officers is the developed ability to act mentally, to select the necessary information from a large amount of it; making the right decisions in the situations of lack of time (Bouchard, Blair, \& Haskell, Kazmirenko, \& Moiseyev, Ostapovych, Dubova, \& Barko) [26-31].

There are also increased requirements for the communicative potential and speech of police officers. Researchers note that the communicative activity of police officers is unique, it has a number of psychological features, in particular, professional orientation; procedural setting of communication parameters; normativeness (for example, the order of communication of the investigator with the defendants is regulated by the norms of procedural legislation). Researchers emphasize the importance of taking into account the peculiarities of police communication in a criminal environment - the presence of criminal jargon as a specific means of communication, tattoos, etc., knowledge of the criminal subculture of communication.

\section{CONCLUSIONS}

Successful mastery of the profession of police officers of cargo and mobile objects security and the effectiveness of further activities are largely determined by the degree of formation of some individual psychological qualities of the police officer.

Here is a list of the following qualities (in descending order of importance): a sufficient level of functional activity of the brain (the value of omega potential is in the range of 20-40 mV); sufficient speed of simple visual-motor reaction - no more than $230 \mathrm{~ms}$; sufficient speed of reaction to a moving object - the average value of the deviation does not exceed $50 \mathrm{~ms}$; strong or medium-strong indicators of the course of nervous processes; high and medium lability of nervous processes (number of touches for $30 \mathrm{~s}$ - more than 160); sufficient level of distribution and speed of switching attention (according to the results of the Grunbaum test, the time does not exceed $20 \mathrm{~s}$, the number of errors is not more than 2); sufficient amount of RAM - the number of memorized words - not less than 6 out of 10; average and higher level of verbal intelligence (not less than 94 IQ); average and higher level of practical intelligence (not less than 96 IQ); formation of communicative abilities (according to the Leary test, the indicators of octants 1, 2, 3, 4, 7, 8 in the profile do not exceed 8 points; the indicators of octants 5,6 - do not exceed 7 points); formation of motivation (indicators of selfactualization according to the Jones-Crandall test - not less than 38 points); presence on the first positions of motives of structuring of work, presence of feedback; interesting and socially useful work; recognition by others; independence, autonomy and self-improvement; setting bold goals; stenic characterological profile: according to the ITI, the indicators of scales $1,2,4,8$ are in the range of 5-7 points; and scales 3, 5, 6 and 7 - do not exceed 5 points; according to the BFI - indices of honesty and openness of experience - are more than 30 points, agreeableness - does not exceed 40, and neuroticism does not exceed 20 points.

Here are also indicators that indicate the professional unfitness of a person to work as a police officers of cargo and mobile objects security: low level of functional activity of the brain (the value of Omega potential less than $20 \mathrm{mV}$ or more than $40 \mathrm{mV}$ ); low speed of simple reaction - more than $230 \mathrm{~ms}$, low speed of reaction to a moving object - the average value of the deviation exceeds $50 \mathrm{~ms}$; weak type of nervous system; low level of lability of the nervous system; insufficient level of distribution and speed of switching attention (when performing the Grunbaum test, the time exceeds $20 \mathrm{~s}$, the number of errors is more than 2); insufficient memory (less than 6 words are memorized); low level of intelligence, verbal intelligence - less than 94 IQ, practical intelligence - less than 96 IQ); unsatisfactory personal characteristics: the presence of the results of the ITI in the personal profile of increased indicators on hypostenic scales: 7, 6, 5 - more than 5 points, increased indicators of stenic scales: 2, 3, 4 - more than 7 points; according to the results of BFI - the value of the neuroticism scale exceeds 19 points; agreeableness scale exceeds 41 points; integrity scales are greater than 30 points, experience openness scales are less than 30 points; low level of communicative potential (according to the results of the Leary test, indicators of scales 1,2 , $3,4,7,8$ exceed 8 points; indicators of scales 5,6 exceed 5 points; unfavorable indicators of emotional and volitional sphere of personality (propensity to conflict, avoidance difficulties and responsibilities, low emotional stability in extreme situations, etc.), insufficient development of self-actualization (according to the Jones- Crandall test score less than 38 points), dominance in the first positions of motives not related to the content of service activities, low level of development of special professional abilities, defects and violations of the analyzers, low level of formation of cognitive processes.

The prospect of further research is seen in the study of psychological aspects of professional activities of 
police officers of other bodies and units of the Ministry of Internal Affairs of Ukraine, as well as the development

\section{REFERENCES}

[1] Pro orhanizatsiiu sluzhbovoi diialnosti politsii okhorony $\mathrm{z}$ pytan zabezpechennia fizychnoi okhorony obiektiv, nakaz vid 07.07.2017 № 577, available at: https://zakon.rada.gov.ua /laws/show/z0989-17

[2] Ostapovych, V.P. Boiko-Buzyl, Yu.Iu. Barko, V.I. ta in. (2021), Profesiohramy pratsivnykiv orhaniv politsii okhorony (za napriamamy sluzhbovoi diialnosti): naukovyi dovidnyk, Kyiv, DNDI MVS Ukrainy.

[3] Pro orhanizatsiiu sluzhbovoi diialnosti politsii okhorony $\mathrm{z}$ pytan zabezpechennia fizychnoi okhorony obiektiv, nakaz vid 07.07.2017 № 577, available at: https://zakon.rada.gov.ua/ laws/show/z0989-17

[4] Konstytutsiia Ukrainy, Zakon Ukrainy vid 28.06.1996 № 254k/96-VR. Potochna redaktsiia vid 30.09.2016. Vidomosti Verkhovnoi Rady Ukrainy. 1996. № 30 (vid 23.07.1996). St. 141, available at: http://zakon5.rada.gov.ua/laws/show /254k/96-vr

[5] Korystin, Oleksandr and Svyrydiuk, Nataliia (2020), "Methodological principles of risk assessment in law enforcement activity", Nauka i Pravookhorona, vol. 3 (49), pp. 191-198, DOI: 10.36486/np.2020.3(49).19

[6] Korystin, Oleksandr and Svyrydiuk, Nataliia (2021), "Formation of security competences in law enforcement activities", Nauka i Pravookhorona, vol. 1 (51), pp. 191-198, DOI: 10.36486/np.2021.1(51).20

[7] Natsionalnyi klasyfikator Ukrainy "Klasyfikator profesii”" DK 003:2010, zatverdzhenyi nakazom Derzhspozhyvstandartu Ukrainy vid 28.07.2010 № 327 (chynnyi vid 01.11.2010), available at: https://hrliga.com/docs/327_KP.htm

[8] Pro Natsionalnu politsiiu: Zakon Ukrainy vid 10.12.2015 № 889-VIII (2015), Vidomosti Verkhovnoi Rady Ukrainy, no. 40-41 (vid 09.10.2015), ST. 379, available at: https://zakon.rada.gov.ua/laws/show/580-19

[9] Barko, V. Bek, A. and Tatarenko, A. (2002), "Developing of Police Management Training in Post-Soviet Societies: Understanding the Context and setting the Agenda", Police Quarterly, vol. 5, no. 4, pp. 447-469.

[10] Barko, V. Bek, A. and Tatarenko A. (2003), "Women Militia Officers inUkraine: Exploring their Experiences in a Post-Soviet Policing of proposals to improve the psychological support of their official activities.

Organization", Policing: An International Journal of Police Strategies and Management, vol. 26, no. 4, pp. 108-120.

[11] Barko, V. Okhrimenko, I. Medvediev, V. Vagina, O. and Okhrimenko, S. (2020), "Professional Psychological Profile of a Modern Patrol Officer as the Basis of Efficient Official Activities", Postmodern Openings, vol. 11 (3), pp. 1-19. DOI:10.18662/po/11.3/197

[12] Barko, V. Okhrimenko, I. Ostapovich, V. Medvediev, V. and Sprynchuk, S. (2020), "Professional psychological potential of a modern police manager as the basis for the formation of an effective managerial system", International Journal of Applied Exercise Physiology, vol. 9 (11), pp. 203-214, available at: http://www.ijaep.com/index.php/

IJAE/article/view/1196

[13] Barko, V. Ostapovich1, V. Okhrimenko, I Yevdokimova, O. Ponomarenko, Y. (2020), "Psychological Profile of Successful Criminal Police Officer", International Journal of Applied Exercise Physiology, vol. 9 (3), pp. 120-133, available at: http://www.ijaep.com/index.php /IJAE/article/view/755

[14] Okhrimenko, I. Yevdokimova, O. Shvets, D. Pakhomova, N. and Fediy, O. (2020), "Police Training or Police Education: View on the Matter", International Journal of Applied Exercise Physiology, vol. 9 (12), pp. 129-136, available at: http://ijaep.com/index.php/IJAE/article/view/1244

[15] Arnold Adimabua Ojugo and Obinna Nwankwo (2021), "Tree-classification Algorithm to Ease User Detection of Predatory Hijacked Journals: Empirical Analysis of Journal Metrics Rankings", International Journal of Engineering and Manufacturing (IJEM), vol. 11, no. 4, pp. 1-9. DOI: $10.5815 /$ ijem.2021.04.01

[16] Gaurav Kumar and Rajeev Kumar (2021), "Analysis of Arithmetic and Huffman Compression Techniques by Using DWT-DCT", International Journal of Image, Graphics and Signal Processing (IJIGSP), vol. 13, no. 4, pp. 63-70. DOI: $10.5815 /$ ijigsp.2021.04.05

[17] Jiashu Xu (2021), "A Review of Self-supervised Learning Methods in the Field of Medical Image Analysis", International Journal of Image, Graphics and Signal Processing (IJIGSP), vol .13, no. 4, pp. 33-46. DOI: 10.5815/ijigsp.2021.04.03 
[18] Kh'yell, L. and Zigler, D. (1997), Teorii lichnosti (osnovnyye polozheniya, issledovaniya $i$ primeneniye), SPb.: Piter, Rossiia.

[19] Sobchyk, L.M. (2003), Psykholohyia yndyvydualnosty, SPb.: Yzd-vo «Rech», Rossiia.

[20] Leongard, K. (1981), Aktsentuirovannyye lichnosti. Translation from german, Science, Moscow, Rossiia.

[21] Yeliseyev, O.P. (2006), Practicum on personality psychology, SPb: Peter, Rossiia.

[22] Leary, T. (2001), The Study of communicative and characterological trends / Diagnostics of interpersonal interaction Leary / Practical psychodiagnostics, Methods and tests. Tutorial, Ed. and comp. Raygorodsky D.Y. Samara, pp. 408-418.

[23] Richi, Sh. and Martin, P. (2004), Upravleniye motivatsiyey, Moscow: Yuniti-Dana, Rossiia.

[24] Hudson, D. (2014), Building trust between communities and local police, The White House site 01.12.2014, available at: https://www.whitehouse.gov/blog/2014/12/01/buil ding-trust-between-communities-and-local-police

[25] Barko, V. Irkhin, Yu. Neshcheret T. ta in. (2007), Profesiohrafichnyi opys osnovnykh vydiv diialnosti $v$ orhanakh vnutrishnikh sprav Ukrainy, Kyiv: RVTs KNUVS; DP “Drukarnia MVS”.
[26] Ostapovych, V. Dubova, I. Barko, V. ta inshi (2018), Profesiohramy za osnovnymy vydamy politseiskoi diialnosti: nauk.-prakt.posib., Kyiv: DNDI MVS Ukrainy; FOP Kandyba T.P.

[27] Bouchard, C. (2007), Physical activity and health, Champaign: Human Kinetics.

[28] Cochraine, R. Tett, R. and Vandecreek, L. (2003), "Psychological Testing and the Selection of Police Officers National Survey", Criminal Justice and Behavior, vol. 30 (5), pp. 511-537, available at: https://www.researchgate.net/publication/2477436 68

[29] Dunnette, M. and Borman W. (1979), "Personnel Selection and Classification Systems", Annual Review of Psychology, vol. 30, no. 1. pp. 477-525 DOI: 10.1146/annurev.ps.30.020179.002401

[30] Gerald V. Barrett, Rosanna F. Miguel, Jennifer M. Hurd, Sarah B. Lueke and James A. Tan (2003), "Practical Issues in the Use of Personality Tests in Police Selection", Public Personnel Management, vol. 32, no. 4, Winter. DOI: $10.1177 / 009102600303200403$.

[31] John, O. Naumann, L. and Soto, C. (2008), "Paradigm Shift to the Integrative Big-Five Trait Taxonomy: History, Measurement, and Conceptual", Handbook of personality: Theory and research, New York: Guilford Press, pp. 114-158 